University of Wollongong

Research Online

Faculty of Engineering - Papers (Archive)

Faculty of Engineering and Information

Sciences

$1-1-2012$

\title{
The role of ballast fouling characteristics on the drainage capacity of rail substructure
}

Nayoma Tennakoon

University of Wollongong, nayoma@uow.edu.au

Buddhima Indraratna

University of Wollongong, indra@uow.edu.au

Cholachat Rujikiatkamjorn

University of Wollongong, cholacha@uow.edu.au

Sanjay Nimbalkar

University of Wollongong, sanjayn@uow.edu.au

Tim Neville

Australian Rail Track Corporation Ltd

Follow this and additional works at: https://ro.uow.edu.au/engpapers

Part of the Engineering Commons

https://ro.uow.edu.au/engpapers/4463

\section{Recommended Citation}

Tennakoon, Nayoma; Indraratna, Buddhima; Rujikiatkamjorn, Cholachat; Nimbalkar, Sanjay; and Neville, Tim: The role of ballast fouling characteristics on the drainage capacity of rail substructure 2012, 1-4. https://ro.uow.edu.au/engpapers/4463

Research Online is the open access institutional repository for the University of Wollongong. For further information contact the UOW Library: research-pubs@uow.edu.au 


\title{
The Role of Ballast Fouling Characteristics on the Drainage Capacity of Rail Substructure
}

\section{Nayoma Tennakoon}

BSc (Eng) Hons,

$\mathrm{PhD}$ Candidate, Faculty of Engineering,

University of Wollongong, Wollongong City, NSW 2522, Australia

\section{Buddhima Indraratna}

BSc (Hons., Lond.), MSc (Lond.), DIC, PhD (Alberta), FIEAust., FASCE, FGS

Professor of Civil Engineering, Faculty of Engineering,

University of Wollongong, Wollongong City, NSW 2522, Australia

\section{Cholachat Rujikiatkamjorn}

BEng (Hons), MEng (AIT), PhD (Wollongong)

Lecturer, Civil Engineering Division, Faculty of Engineering, University of Wollongong, Wollongong City, NSW 2522, Australia

\section{Sanjay Nimbalkar}

BEng, MTech, PhD (IIT Bombay)

Research Fellow, Faculty of Engineering,

University of Wollongong, Wollongong City, NSW 2522, Australia

\author{
Tim Neville \\ BEng (Hons.) \\ Senior Geotechnical Engineer \\ Australian Rail Track Corporation Ltd. \\ Locked bag 1 Broadmeadow NSW 2289
}

Unit 5, 33 Newton Street Broadmeadow NSW2292

Submitted to: Geotechnical Testing Journal

Author for correspondence:

Prof. B. Indraratna

Professor of Civil Engineering

Faculty of Engineering

University of Wollongong

Wollongong, NSW 2522

Australia.

Ph: +61 242213046

Fax: +61 242213238

Email: indra@uow.edu.au 


\title{
The Role of Ballast Fouling Characteristics on the Drainage Capacity of
}

\author{
Rail Substructure \\ Nayoma Tennakoon ${ }^{1}$, Buddhima Indraratna $^{2}$ FASCE, Cholachat Rujikiathkamjorn ${ }^{3}$,
Sanjay Nimbalkar ${ }^{4}$ and Tim Neville
}

\begin{abstract}
The ballast layer is designed to be free draining, but when the voids of the granular medium are wholly or partially filled due to the intrusion of fine particles, the ballast is considered to be "fouled". In order to ensure acceptable track performance, it is necessary to maintain good drainage within the ballast layer. This paper critically examines the current methods commonly used for evaluating the degree of ballast fouling and, due to their limitations, a new parameter, Void Contaminant Index is introduced. A series of large-scale constant head hydraulic conductivity tests were conducted with different levels of fouling to establish the relationship between the void contamination index and the associated hydraulic conductivity. Subsequently, a numerical analysis was executed to simulate more realistic two-dimensional flow under actual track geometry capturing the drainage capacity of ballast in relation to the void contamination index. In the context of observed test data, the drainage condition of the track could be classified into different categories together with a classification chart capturing the degree of fouling. The contents of this paper have already been considered in track maintenance schemes in the States of Queensland and New South Wales.

Keywords: Ballast, Drainage, Fouling material, Hydraulic conductivity, Void Contaminant Index

${ }^{1}$ Doctoral Student, Centre for Geomechanics and Railway Engineering, School of Civil Engineering, Faculty of Engineering, University of Wollongong, Wollongong City, NSW 2522, Australia

${ }^{2}$ Professor, Centre for Geomechanics and Railway Engineering, School of Civil Engineering, Faculty of Engineering, University of Wollongong, Wollongong City, NSW 2522, Australia

${ }^{3}$ Senior Lecturer, Centre for Geomechanics and Railway Engineering, School of Civil Engineering, Faculty of Engineering, University of Wollongong, Wollongong City, NSW 2522, Australia

${ }^{4}$ Research Fellow, Centre for Geomechanics and Railway Engineering, School of Civil Engineering, Faculty of Engineering, University of Wollongong, Wollongong City, NSW 2522, Australia

${ }^{5}$ Senior Geotechnical engineer, Australian Rail Track Corporation Ltd., Unit 5, 33 Newton Street Broadmeadow NSW 2292, Australia
\end{abstract}




\section{Introduction}

Railways are the most demanded and widely used transport mode in Australia. Conventionally, rail tracks are positioned on a coarse granular medium (i.e., ballast) due to several reasons, including economy (availability and abundance), rapid drainage, and high load bearing capacity. Rail ballast usually contains uniformly graded material creating a sufficiently large pore structure to facilitate rapid (free) drainage. To sustain good track performance, it is essential to maintain rapid drainage in the ballasted track at all times (Selig and Waters, 1994). When ballast is aged and degraded, fine particles accumulate within the voids (i.e., fouling) thus impeding drainage. The process of fouling when becomes extreme can also generate excess pore water pressure under fast moving trains (i.e., high cyclic loading), thereby reducing the track resiliency and stability (undrained) (Indraratna et al., 2010). The maintenance costs of ballasted tracks can be significantly reduced if an accurate estimation of the different types and degree of fouling materials can be related to track drainage.

Apart from reviewing the commonly used method of ballast fouling assessment such as Percentage of Fouling, Fouling Index (Selig and Waters, 1994) and Percentage Void Contamination (Feldman and Nissen, 2002), this paper introduces a new parameter, Void Contaminant Index that represents the actual volume of fouling materials. A numerical seepage analysis is conducted to simulate realistic two-dimensional flow to assess the drainage capacity of the track incorporating experimentally measured hydraulic conductivities associated with different degrees of fouling. The track drainage conditions are categorized in a classification chart of the drainage capacity of the track associated with degree of fouling.

\section{Quantification of ballast fouling}

Fouling material has been defined as the material passing the $9.5 \mathrm{~mm}$ size sieve (Selig and Waters, 1994). Sources of ballast fouling (Figure 1) can be attributed to ballast particle degradation, infiltration of fine foreign particles from the track surface, sleeper wear, as well as sub-ballast and subgrade infiltration (Indraratna et al., 2011). There are two common types of fouling that can be seen in Australia, namely, coal fouling (surface infiltration, Figure 1a) due to spilling of coal from wagons and clay pumping due to soft subgrade instability (Figure $1 b)$.

Selig and Waters (1994) defined the Fouling Index as a summation of percentage (by weight) passing the $4.75 \mathrm{~mm}$ (No. 4) sieve and $0.075 \mathrm{~mm}$ (No. 200) sieve. This parameter may lead to misinterpretation of the actual degree of fouling if the fouled material contains more than one type of material having considerably different specific gravities (e.g., coal and pulverized rock). Alternatively, Feldman and Nissen (2002) defined the Percentage Void Contamination $(P V C)$ as:

$$
P V C=\frac{V_{v f}}{V_{v b}} \times 100
$$

where $V_{v f}$ is the ratio of bulk volume of fouling material and, $V_{v b}$ is the initial voids volume of clean ballast.

The parameter $V_{v f}$ needs to be calculated after compacting the fouling material (Feldmen and Nissen, 2002) that does not always represent the actual volume of fouling accurately in a track environment. In view of the above, a new parameter, Void Contaminant Index (VCI) is proposed herewith that can capture the role of different fouling materials as a modification to the $P V C$. 
$V C I=\frac{V_{f^{\prime}}}{V_{v b}} \times 100$

where $V_{f}$, is actual volume of fouling material within the ballast voids. The detailed information for the field procedure in order to obtain these parameters is given in the appendix. By substituting the relevant soil parameters, Equation (2) can be re-written as:

$V C I=\frac{\left(1+e_{f}\right)}{e_{b}} \times \frac{G_{s b}}{G_{s f}} \times \frac{M_{f}}{M_{b}} \times 100$

where,

$e_{b} \quad=$ Void ratio of clean ballast

$e_{f} \quad=$ Void ratio of fouling material

$G_{s b} \quad=$ Specific gravity of clean ballast

$G_{s f} \quad=$ Specific gravity of fouling material

$M_{b} \quad$ = Dry mass of clean ballast

$M_{f} \quad$ = Dry mass of fouling material

For example, a value of $V C I=50 \%$ indicates that half of the total ballast voids is occupied by the fouling material. The effect of fouling on permeability depends on the type of fouling materials (e.g. coal vs. clay). Therefore, the proper understanding of the nature of fouling materials is pertinent irrespective of the quantity of fouling. For example, sand and coal fouling may not decrease the overall permeability of the track significantly, while clay fouling can decrease the track drainage more dramatically (Selig and Waters, 1994). Figure 2 shows the comparison between FI, PVC and VCI for various ranges of Percentages of Fouling. For instance, let us consider $15 \%$ fouling by mass for coal-fouled, clay-fouled and sand-fouled ballast, where the corresponding VCI values are $78 \%, 65 \%$ and $52 \%$, respectively, and the corresponding $F I$ values are 16, 28, and 15, respectively. It is clear that the coal-fouled and sand-fouled ballast give a very close value to each other (difference of 16-15 =1) in spite of the difference in the specific gravities of coal and sand (quartz), compared to the difference in $V C I(78-52=26)$. The $P V C$ values for the three fouling materials are $54 \%, 48 \%$ and $42 \%$, but these three values are less widely spread $(42-54 \%)$ compared to the range of the $V C I$ values $(52-78 \%)$. Therefore, $V C I$ is more sensitive to the changes of the fouling type and extent, apart from being more realistic as it is the only fouling characterization method that incorporates the specific gravity of the fouling material. Initial placement density of the ballast in the actual rail track is often ascertained as a standard practice in Australia. Most of Australian standards for ballast (AS 2758.7, 1996; TS 3402, 2001) recommend the range of in-situ densities of the ballast. While authors agree that these can vary in the field depending upon the tamping efforts, they can still be considered as reasonable estimates. The ballast degradation also substantially contributes to the ballast fouling. This in turn justifies the need for a more rational parameter such as $V C I$ which can consider the effect of types of fouling material such as coal, clay, sand, and mineral filler resulting from ballast breakage. The need for additional laboratory tests such as specific gravity, moisture content and proper field sampling procedure should be encouraged in order to avoid costly track maintenance works which are often governed by inaccurate assessment of fouling based on mass based fouling indices such as FI. The method for determination of $V C I$ is introduced in the Appendix.

\section{Large-Scale Permeability Test}

To investigate the effect of fouling on the overall hydraulic conductivity of ballast, a series of large scale permeability tests were conducted. 
There are two distribution patterns of fouling material within the ballast voids that can be observed in a fouled, ballasted track. Firstly, fouling material infiltrates from the top of the track and settle to the bottom as shown in Figure 3 (non-uniformly distributed fouling, e.g., coal fouling). In the second case, fouling material accumulates within the voids of ballast due to subgrade pumping as shown in Figure 4 (uniformly distributed fouling e.g., clay fouling). Both fouling patterns were simulated in the large-scale permeability test described in the next section.

\section{Material properties}

The gradation of clean ballast obtained from Bellambi, NSW is illustrated in Figure 5 together with the gradation specified by AS 2758.7 (1996). Fouling materials having different gradation curves (Figure 5) were used. Properties of clean ballast and the fouling materials that have been used in permeability testing are shown in Table 1. When ballast is mixed with coal fines, clayey fine sand and kaolin clay, it is denoted in this paper as coal-fouled, sandfouled and clay-fouled ballast respectively. An initial void ratio $\left(e_{b}\right)$ of 0.69 was determined by (a) saturating the ballast with a known volume of water and (b) the weight-volume relationships.

\section{Specimen preparation}

A large-scale permeameter was employed to measure the hydraulic conductivity associated with different levels of fouling. This chamber could accommodate ballast specimens of 500 $\mathrm{mm}$ in diameter and 300-500 $\mathrm{mm}$ in height (Figure 6). The sample size ratio (diameter of test sample to the maximum particle size of ballast) should be greater than 6 in order to minimize the sample size effects (Marachi et al. 1972, Indraratna et al. 1993). According to AS 1289.6.7.3-1999, the height of the specimen should be greater than at least 5 times the maximum particle size. Also, the thickness of ballast layer in Australian rail track varies between $300 \mathrm{~mm}$ and $500 \mathrm{~mm}$. In view of this, specimen height of $500 \mathrm{~mm}$ was considered appropriate in this study. In order to prevent the wash out of fine particles, a filter membrane was placed at the base of the ballast layer while maintaining a free drainage boundary. The test specimen was placed above the filter membrane and compacted in four equal layers to represent the typical field density.

Two fouling patterns were simulated. For the case of non-uniformly distributed fouling, the ballast layer was compacted, then the fouling material was added from the top and allowed to infiltrate downwards with percolating water. To simulate uniformly distributed fouling, a given volume of kaolin was pre-mixed with the ballast aggregates and then compacted in 5 layers. For $100 \%$ VCI, kaolin was placed at the bottom of the permeameter and then the ballast layer was placed on top of it and compacted using a vibrating plate until the required height was achieved for each layer, with the excess kaolin inevitably squeezed out to the top. The total volume, the weight of the ballast and its gradation were kept equal for each test to maintain a similar initial porosity (or similar voids volume within the ballast). The initial pore structures for all the samples were kept comparable to each other as much as possible. The initial porosities varied within the range of 0.408 to 0.416 .

\section{Testing procedures}

In order to evaluate in-situ track fouling conditions, samples of coal-fouled ballast were collected from sites at Rockhampton (Queensland, Australia), Bellambi (New South Wales, Australia), and samples of clay-fouled ballast from Sydenham (New South Wales, Australia). The laboratory tests to measure their FI, PVC and VCI values and large-scale hydraulic conductivity tests were carried out on samples retrieved at these locations. 
To study the effect of fouling, further extensive laboratory tests were carried out by varying $V C I$ from 0 to 100. Total of 29 tests (Table 2) consisting of 11 tests on coal-fouled ballast, 11 tests on sand-fouled ballast and 7 tests on clay-fouled ballast were performed using largescale permeability apparatus (AS: 1289.6.7.1). Parson (1990) reported that for fresh ballast, linear Darcy's law is still valid at low hydraulic gradients (less than 4). Therefore, Darcy law considering laminar flow was adopted in this study. The fouled specimen was saturated for at least 24 hours. These tests were conducted under steady state flow subjected to a $1.5 \mathrm{~m}$ head of water using an adjustable overhead tank. The steady flow conditions were ensured by obtaining three consecutive $\mathrm{k}$ values with minimum variation to about less than $1 \%$.

Hydraulic conductivity of the equipment including base materials (crushed uniformly graded ballast $63 \mathrm{~mm}$ size aggregates) was tested before the placement of the ballast to obtain the loss coefficient of the equipment. The loss coefficient was incorporated to obtain the accurate measured permeability.

\section{Results and Discussions}

As expected, the overall hydraulic conductivity always decreases with an increase in $V C I$ (Figure 7). The current test results show that a 5\% increase of $V C I$ decreases the hydraulic conductivity by a factor of at least 200 and 1500 for ballast contaminated by coal and fine clayey sand, respectively. However, this reduction in permeability would not significantly affect the required minimum drainage capacity for acceptable track operation. Beyond $V C I$ of $75 \%$, further reduction in hydraulic conductivity becomes marginal as it approaches the hydraulic conductivity of the fouling material itself. The above observations are also in line with the laboratory measurements of sand-gravel mixtures reported by Jones (1954), whereby a high percentage of sand (greater than 35\%) in gravel would provide a hydraulic conductivity close to that of the sand itself.

Figure 8 shows the variation of hydraulic conductivity for clay- fouled ballast for the case where the fouling material is uniformly distributed. At low levels of VCI (less than 10\% $\mathrm{VCI}$ ), the overall hydraulic conductivity of ballast is relatively unaffected. Beyond VCI $=90 \%$, the overall permeability of fouled ballast is almost the same as that of kaolin.

\section{Analytical and empirical models for hydraulic conductivity}

In the past, various researchers have attempted to model the hydraulic conductivity of granular soils.; e.g., Hazen (1911) and Casagrande (1937) empirical relations and KozenyCarman (Kozeny, 1927; Carman, 1956) analytical equation (Salem, 2001; Carrie, 2003; Costa, 2006; Yin, 2009; Courcelles et al., 2011). While these models work well for some types of granular materials such as sands and silts, for coarse-grained aggregate such as ballast having a larger and inter-connected pore structure, the change of hydraulic conductivity with respect to the porosity is usually insensitive, unless a large amount of fines are accumulated within the voids. To represent the hydraulic conductivity $(k)$ of a mixture of granular and fine-grained soil, Koltermann and Gorelick (1995) proposed:

$k=\frac{d_{f p}^{2} \phi_{f p}^{3}}{180\left(1-\phi_{f p}\right)^{2}}$

where $\phi_{f p}$ is the composite porosity of the mixture and $d_{f p}$ is the representative grain diameter. The above model assumes fine particles to be uniformly distributed throughout the voids. For example, in the field, coal fouling accumulates more towards the bottom of the ballast layer, i.e., by vertical migration under rainwater percolation and vibration upon the passage 
of trains. Therefore, to determine the equivalent permeability of ballast that is contaminated with non-uniformly distributed fouled material, a layer by layer simplification may need to be considered. An analytical model based on a twin layer permeability theory is considered herewith, assuming only the vertical flow (Figure 3).

According to Figure 4 , the volume of ballast voids occupied by fouling material $\left(V_{v b . h}\right)$ within the ballast layer of height $(h)$ can be written as:

$V_{v b . h}=e_{b} V_{s b} \frac{h}{L}$

where $e_{b}, V_{s b}$ and $L$ are the void ratio of clean ballast, solid volume of the clean ballast, and height of the overall ballast layer, respectively. The dry density of the fouling material $\left(\rho_{s f}\right)$ can be written as:

$\rho_{s f}=\frac{G_{s f}}{\left(1+e_{f}\right)} \rho_{w}$

where $e_{f}$ and $G_{s f}$ are the void ratio and specific gravity of fouling material, respectively, and $\rho_{w}$ is the density of water. The dry mass of fouling material $\left(M_{f}\right)$ can now be written as:

$M_{f}=V_{v b . h} \rho_{s f}$

Combining Equations (5) and (6), the dry mass of fouling material, $M_{f}$ can be calculated by:

$M_{f}=\frac{e_{b}}{1+e_{f}} \times \frac{G_{s . f}}{G_{s . b}} \times M_{b} \times \frac{h}{L}$

Assuming Darcy flow to be perpendicular to the surface, the overall hydraulic conductivity $(k)$ at the clean and fouled ballast layers in tandem can be represented by:

$k=\frac{L}{\frac{(L-h)}{k_{b}}+\frac{h}{k_{f}}}$

where $k_{b}$ and $k_{f}$ are the hydraulic conductivities of clean and fouled ballast layers, respectively. Experimental data will also confirm later that when VCI is very high (greater that $90 \%$ ), the hydraulic conductivity of fouled ballast layer attains almost the same value as that of the fouling material itself (Figure 7). As the VCI of the bottom fouled ballast layer $(h)$ is $100 \%$, the hydraulic conductivity of that layer $k_{f}$, represented in Equation (9) can be assumed to be the same as that of the fouling material itself. By combining Equations (3), (8) and (9) the equivalent hydraulic conductivity for ballast mixed with the contaminating fines (e.g. coal) can be obtained as:

$k=\frac{k_{b} \times k_{f}}{k_{f}+V C I / 100 \times\left(k_{b}-k_{f}\right)}$

The calculated hydraulic conductivity of fouled ballast based on the Equation 10 was close to that of the coal-fouled material obtained from sites at Rockhampton (Queensland), Bellambi (NSW), and clay-fouled ballast from Sydenham (NSW). Figure 7 shows that computed values of hydraulic conductivity based on Equations (6) and (12) are in good agreement with the experimental data. Figure $7 \mathrm{~b}$ shows that the proposed Equation (10) offers a better prediction than that by Koltermann and Gorelick (1995) who do not address the nonuniformity of fouling.

\section{Determination of track drainage capacity using a two-Dimensional seepage model}

As flow through ballast track can occur in both vertical and horizontal directions, a 2-D seepage analysis was conducted using the finite element software, SEEP-W (GeoStudio, $2007 \mathrm{a}$ and $2007 \mathrm{~b}$ ), to determine the drainage capacity with respect to various fouling 
conditions. Hydraulic conductivity values corresponding to different $V C I$ obtained from experimental results (Figure 8) were used as input parameters in the analysis. For most largesize granular materials, the hydraulic conductivity of the granular assembly tends to be isotropic. This has been proven in many past studies carried out for rockfill materials (Hirschfeld, 1973), the hydraulic conductivity of coarse granular materials is often dictated by the lower particle fraction size for which $15 \%$ by mass is finer. The difference in values of $k_{h}$ and $k_{v}$ for coarse aggregates is considerably less than those for fine grained materials such as silt and clay. The pore structure for coarse granular materials along the vertical or horizontal directions is random and therefore in this study $k_{v}$ and $k_{h}$ are often assumed to be same. The vertical cross section of a typical Australian track is shown in Figure 9a and due to symmetry, a finite element discretization of one-half track is considered in Figure 9b. Three types of boundary conditions were applied to the finite element model. While a free drainage boundary condition was used at the top of the shoulder ballast surface, along the centreline, and at the bottom of the ballast bed, an impermeable boundary was applied at the bottom of the ballast bed. A hydraulic head equal to the track height was assumed at the top surface for calculating the steady state discharge $(q)$. Erosion of fouled materials is neglected in this simplified model. To simulate 3 possible scenarios for track fouling, three models were carried out for clay (kaolin) fouled ballast.

Model 1: Newly constructed track: The entire track is divided into three equal horizontal layers (100mm each) and the hydraulic conductivity values corresponding to different $V C I$ values are employed (Figure 10a).

Model 2: Fouling track subjected to undercutting: The track is divided into two horizontal layers and the bottom ballast layer is characterised by $V C I$ of $100 \%$, while the top layer contains clean ballast (Figure 10b). The thickness of clean ballast layer is varied to determine the minimum depth of clean ballast to satisfy acceptable drainage.

Model 3: Track subjected to shoulder cleaning: The whole track is divided into 4 parts, shoulder ballast and 3 horizontal ballast layers with different values of $V C I$ (Figure 10c).

Based on the experimental results as shown in Figure 8, the hydraulic conductivity with $V C I$ relationship is employed for the finite element model.

\section{Classification of the track drainage}

Based on Pilgrim (1997) and ARTC (2006), the rainfall in Australia usually varies from 125 $\mathrm{mm} / \mathrm{hr}$ to $175 \mathrm{~mm} / \mathrm{hr}$ from one state to another. In this study, a maximum rainfall intensity of $150 \mathrm{~mm} / \mathrm{hr}$ was adopted and this would correspond to a critical flow rate $\left(Q_{c}\right)$ of $0.0002 \mathrm{~m}^{3} / \mathrm{s}$ over the unit length of the track.

From the seepage analysis, the maximum drainage capacity $(Q)$ of the ballast layer can be determined for various levels and conditions of fouling. When track drainage capacity is equal to or lower than what is required for a given rainfall rate, then the fouled track is considered to be impermeable. In this context, a ratio between the computed track drainage capacity and the critical flow $\left(Q / Q_{c}\right)$ is introduced as a dimensionless index to classify the drainage condition as stipulated in Table 3. If the ratio $Q / Q_{c}$ equals 1 , track becomes saturated under the given rainfall. When the ratio $\mathrm{Q} / \mathrm{Q}_{\mathrm{c}}$ is greater than 1 , the track drainage is classified into various categories i.e. "Acceptable drainage", "Good drainage", as well as "Free drainage" and when it becomes less than 1, the drainage is classified as "Poor drainage", "Very poor drainage", and "Impervious" based on the output of the numerical SEEP/W analysis. It is pertinent to know that the permeability values employed in the SEEP/W analysis were chosen in accordance with the drainage criteria specified by Terzaghi and Peck (1967).

\section{Seepage Data Interpretation}


Figure 11 shows a typical output of numerical analysis using $S E E P-W$ software. The rain water percolating from the top boundary moves laterally outward due to the presence of impermeable boundary at the bottom. A shift in the direction of flow at the interface between clean and fully fouled ballast $(V C I=100 \%)$ induces greater travel path and thus inhibit rapid dissipation of water. Tables 4-6 and Figure 12 present the results obtained from the analysis of Models 1, 2 and 3, respectively. The drainage classification in Table 4-6 are selected based on the track drainage classification in accordance with drainage capacity criteria (Table 3) adopted in the current study. Based on Model 1 (Figure 10a), as long as the top ballast layer is clean, the track can be classified either as 'free drainage' or as 'acceptable drainage'. In contrast, if the top layer has $V C I>50 \%$ lying on relatively clean bottom ballast layer, then the drainage capacity can be considered to be 'poor'. As expected, when all layers have VCI $>50 \%$, then the track is considered to be of 'very poor drainage', thereby requiring maintenance. This seepage analysis implies that it is not always mandatory to replace the entire ballast volume unless the top layer of the track is also fouled with $V C I$ exceeding $50 \%$. In practice, the common and convenient ballast maintenance schemes include either the shoulder ballast cleaning or the top ballast cleaning (under cutting) or both. This analysis clearly suggests that replacing or cleaning the ballast from the shoulder can be adequate, when the top ballast layer has a VCI less than 50\%. It can also be seen that when VCI of the shoulder ballast exceeds $50 \%$, it acts as a flow barrier, and the track drainage capacity decreases significantly to be categorized as of 'poor drainage'. Moreover, the cleaning of the shoulder ballast alone will be ineffective if the top ballast layer is fouled significantly ( $V C I>$ $50 \%$ ). Under these circumstances, ballast cleaning via under cutting or total ballast replacement by maintenance machinery should be employed. The analysis also shows that as long as a clean ballast thickness of at least $100 \mathrm{~mm}$ is available at any time, then the overall track will have sufficient drainage.

\section{Conclusions}

In this study, a new parameter termed as Void Contaminant Index (VCI), incorporating the effects of void ratios, specific gravities and gradations of both fouling material and ballast is proposed. It is shown that VCI captures the fouling of ballast well and can be adopted as a more realistic fouling index, especially when the fouling material has a specific gravity significantly different than the rock aggregates. Study of one-dimensional flow was imperative for investigating the influence of the degree of fouling on the overall hydraulic conductivity of fouled ballast. An analytical approach based on a twin layer permeability concept was proposed to predict the hydraulic conductivity of fouled ballast with a nonuniform distribution of fouling material with depth. This analytical approach was well supported by a series of constant head permeability tests carried out using a specially designed large-scale permeability apparatus. The results confirmed that the hydraulic conductivity decreased with the increase in $V C I$, and that the critical conditions in view of track maintenance would occur when $V C I$ exceeded $50 \%$ for clay fouling. Initially, even a small increase in VCI leads to a significant decrease in the hydraulic conductivity of the ballast, but beyond a certain limit of $V C I$ ( $50 \%$ for coal and $90 \%$ for clay) the hydraulic conductivity of fouled ballast converges to that of fouling materials itself.

Based on the hydraulic conductivity of ballast having different $V C I$, the drainage capacity of the track was determined using a two-dimensional, finite element seepage analysis applied to actual track geometry. It is shown that both the location and the extent of fouling play an important role when assessing the overall track drainage capacity. In this paper, the drainage condition of the track has been proposed based on typical high rainfall intensity in Australia and the corresponding track drainage capacity. Ballast cleaning using the undercutting method is recommended when the VCI of the top $100 \mathrm{~mm}$ of the ballast layer exceeds $50 \%$. 
When the shoulder ballast is fouled to more than $50 \%$ VCI, then the cleaning or replacement of the track shoulder is also required to maintain an acceptable track drainage capacity. If the shoulder ballast is fouled to a high level (i.e. $V C I>50 \%$ ), then 'poor drainage' can occur even if the other ballast layers are relatively clean.

The design chart developed on the basis of current testing and analysis offers very useful guidelines for facilitating the decisions made by track engineers. The $V C I$ and its implications have already been adopted by some rail organisations in the States of Queensland and New South Wales, through collaboration with the Authors under the auspices of the Cooperative Research Centre for Rail Innovation (CRC-Rail). Nevertheless, the contents of this paper have been based on a limited number of divisions within the ballast bed with several conveniently selected levels of fouling. To evaluate the track drainage capacity to a higher level of accuracy, then a more sophisticated numerical model having a larger number of discretized ballast layers with a wider variation of corresponding $V C I$ values will be required.

\section{Acknowledgement}

The financial support from Rail-CRC is gratefully appreciated. The Authors would like to thank RailCorp, Queensland Rail, ARTC for their support. The assistance of Mr William Clayton in editing the paper is gratefully acknowledged. The contributions by David Christie (Formerly, Senior Geotechnical Advisor, RailCorp (Sydney)) and Sandy Pfeiffer (Senior geotechnical advisor RailCorp, (Sydney)) are gratefully appreciated. The technical assistance by Mr. Alan Grant and Mr. Ian Laird during the laboratory work is deeply appreciated. 


\section{Appendix: Determination of $\mathrm{VCI}$ in the field}

The method for determining in-situ ballast density inspired after Selig and Waters (1994) is adopted to determine $V C I$, and is introduced in this Appendix. The ballast is excavated in several layers so that the fouled ballast layer is properly identified. The stepwise procedure is illustrated below for the case of two layers (Figure A1):

1) Remove the first ballast layer and mark (or measure) its thickness establishing a datum. Fill the hole with a known volume of water $\left(V_{l}\right)$.

2) Remove the second ballast layer.

3) Fill the remaining hole with a known volume of water $\left(V_{2}\right)$.

4) Using $9.5 \mathrm{~mm}$ sieve, separate the fouling material from ballast particles.

5) Determine the dry weights of the clean ballast $\left(\mathrm{M}_{1 . b}, \mathrm{M}_{2 . \mathrm{b}}\right)$ and the dry weights of the fouling material $\left(\mathrm{M}_{\mathrm{f} 1}\right.$ and $\left.\mathrm{M}_{\mathrm{f} 2}\right)$ for layer 1 and 2 respectively.

6) Determine the specific gravities of ballast particle $\left(G_{s}\right)$ and fouling material $\left(G_{s . f}\right)$

7) Calculate the initial void ratio of ballast $\left(e_{b}\right)$ for the initial density of the ballast $\left(\rho_{b}\right)$ when the track was constructed.

$$
e_{b}=\left(\frac{G_{s b} \rho_{w}}{\rho_{b}}\right)-1
$$

8) Calculate the void ratio of fouling materials $\left(e_{f 1}, e_{f 2}\right)$ for layer 1 and 2 respectively.

$$
\begin{aligned}
& e_{f 1}=\left(e_{b} \frac{M_{b 1}}{M_{f 1}} \frac{G_{s f 1}}{G_{s b}}\right)-1 \\
& e_{f 2}=\left(e_{b} \frac{M_{b 2}}{M_{f 2}} \frac{G_{s f 2}}{G_{s b}}\right)-1
\end{aligned}
$$

9) Determine the $V C I$ for each layer substituting $G_{s b}, G_{s f 1}, G_{s f}, M_{f 1}, M_{f 2}, M_{b 1}, M_{b 2}, e_{f 1}, e_{f 2}$, and $e_{b}$ using Equation (A3).

$$
\begin{aligned}
& V C I_{1}=\frac{\left(1+e_{f 1}\right)}{e_{b}} \times \frac{G_{s b}}{G_{s f 1}} \times \frac{M_{f 1}}{M_{b 1}} \times 100 \\
& V C I_{2}=\frac{\left(1+e_{f 2}\right)}{e_{b}} \times \frac{G_{s b}}{G_{s f 2}} \times \frac{M_{f 2}}{M_{b 2}} \times 100
\end{aligned}
$$

One of the salient benefits of this approach is that it accurately assesses how the fouling materials are distributed within the pore structure of the ballast that is lacking in previously established indices such as $F I$ and $P V C$. The track drainage capacity is also governed by both the location and the extent of fouling and this information can be accurately obtained by employing the field procedure as described here. Also when there are different fouling materials with different specific gravities, the resulting different volumes of fouling materials occupying the ballast voids can be correctly captured using this $V C I$ as shown in Figure 2. 


\section{Reference}

ARTC (2006). Track Drainage -Design and Construction. Engineering Practices Manual Civil Engineering, Australian Rail Track Corporation. Issue A.

Australian Standard: AS 1289.6.7.3 (1999). Methods of testing soils for engineering purposes - Soil strength and consolidation tests - Determination of permeability of a soil Constant head method using a flexible wall permeameter.

Australian Standard: AS 2758.7 (1996). Aggregates and rock for engineering purposes; Part 7: Railway ballast.

Carman, P. E. ( 1956). "Flow of Gases Through Porous Media", Academic, New York.

Carrie, W. D. (2003). "Goodbye, Hazen; Hello, Kozeny-Carman." Journal of Geotechnical and Geoenvirnmental Engineering., 129(11), 1054-1056.

Casagrande, A. (1937). "Seepage through Dams in contribution to soil mechanics." 19251940. Boston, Boston Society of Civil Engineering.

Costa, A. (2006). "Permeability-porosity relationship: A reexamination of the KozenyCarman equation based on a fractal pore-space geometry assumption" Geophysical Research Letters, VOL. 33, L02318, 1-5.

Courcelles, B., Modaressi-Farahmand-Razavi, A., Gouvenot, D., and Esnault-Filet, A. (2011). "Influence of Precipitates on Hydraulic Performance of Permeable Reactive Barrier Filters", International Journal of Geomechanics ASCE, Vol. 11, No. 2, 142151.

Feldman, F. and Nissen, D. (2002). "Alternative Testing Method for the Measurement of Ballast Fouling: Percentage Void Contamination." Conference on Railway Engineering, Wollongong, RTSA., 101-109.

GeoStudio (2007a). "GeoStudio Tutorials includes student edition lessons", 1st edn. GeoSlope International Ltd., Calgary

GeoStudio (2007b). "Seep/W for finite element seepage analysis, , users manual". Geo-Slope International Ltd., Calgary, Alberta, Canada.

Hazen, A. (1911). "Discussion of "Dams on Sand Foundation". Transactions of American Society of Civil Engineering, 73-199.

Hirschfeld, R. C. (1973) Embankment-dam engineering, New York: John Wiley \& Sons.

Indraratna, B., Nimbalkar, S.S., and Tennakoon, N. (2010). "The Behaviour of Ballasted Track Foundations: Track Drainage and Geosynthetic Reinforcement" Proc., GeoFlorida 2010 Conference on Advances in Analysis, Modeling, \& Design.,ASCE, Orlando, Florida, February 20-24

Indraratna .B., Salim .W., and Rujikiatkamjorn .C. (2011) "Advanced Rail Geotechnology Ballasted Track": CRC Press/Balkema.

Indraratna, B., Wijewardena, L.S.S., \& Balasubramaniam, A.S. (1993). "Large-scale triaxial testing of greywacke rockfill", Géotechnique 43, No. 1, 37-51

Jones, C. W. (1954). "The permeability and settlement of laboratory specimens of sand and sand-gravel mixtures.” ASTM: Philadelphia. Special Technical Publication No. 163:, 68-78.

Koltermann, C. E. and Gorelick, S. M. (1995). "Fractional packing model for hydraulic conductivity derived from sediment mixtures." Water Resources Research 31(12), 3283-3297.

Kozeny, J. (1927), "Ueber kapillare Leitung des Wassers in Boden", Wien Akad. Wiss., Vol.136, part 2a, p. 271.

Marachi, N. D., Chan, C. K. \& Seed, H. B. (1972). "Evaluation of properties of rockfill materials", Journal of the Soil Mech. and Found. Div., ASCE, 98, No. SM1, 95-114.

Parson. B.K (1990) "Hydraulic conductivity of railroad ballast and track substructure drainage," Geotechnical report: University of Massachusetts. 
Pilgrim, D. H. (1997). “Australian rainfall and runoff: a guide to flood estimation”, Institution of Engineers, Australia, 15-54.

Rail Infrastructure Corporation of NSW. (2001). "Specification for supply of aggregates for ballast." TS 3402, Sydney, Australia.

Salem, H. (2001). "Application of the Kozeny-Carman Equation to Permeability Determination for a Glacial Outwash Aquifer, Using Grain-size Analysis", Energy Sources, Volume 23, No 5, 461-473.

Selig, E. T. and Waters, J. M. (1994). "Track Geotechnology and Substructure management." Thomas Telford, U.K.

Terzaghi, K. and Peck, P.B. (1967) "Soil Mechanics in Engineering Practice." New York. John Willey \& Sons.

Yin, J. H. (2009). "Influence of Relative Compaction on the Hydraulic Conductivity of Completely Decomposed Granite in Hong Kong", Canadian Geotechnical Journal, Vol. 46, 1229-1235. 


\section{List of Tables}

Table 1: Properties of clean ballast and fouling material

Table 2: Details of experimental test programme

Table 3: Drainage capacity criteria

Table 4: Track drainage classification based on Model 1

Table 5: Track drainage classification based on Model 2

Table 6: Track drainage classification based on Model 3

\section{List of Figures}

Figure 1: ballast fouling (a) surface infiltration and (b) subgrade infiltration

Figure 2: Comparison between Fouling Index, Percentage Void Contamination and Void Contaminant Index for various ranges of Percentage of Fouling

Figure 3: Schematic diagram of non-uniform fouled ballast

Figure 4: Fouling status (a) fresh ballast, (b) partially fouled ballast and (c) fully fouled ballast

Figure 5: Gradations of clean ballast and fouling materials

Figure 6: Schematic diagram of large-scale permeability test apparatus

Figure 7: Variation of hydraulic conductivity vs. Void Contaminant Index for (a) coal fouled ballast and clayey fine sand fouled ballast and (b) coal fouled ballast with existing model Figure 8: Variation hydraulic conductivity with Void Contaminant Index for uniform clay fouled ballast

Figure 9: (a) Vertical cross section of the typical ballast layer used in seepage analysis and (b) Discretization of one-half track

Figure 10: Fouled ballast patterns (a) Model 1, (b) Model 2 and(c) Model 3

Figure 11: Typical output of numerical Seepage analysis (Model 2)

Figure 12: Maintenance chart

Figure A1: Field test set up for determining VCI 
Table 1: Properties of clean ballast and fouling material

\begin{tabular}{|l|c|c|c|c|}
\hline \multicolumn{1}{|c|}{ Material } & $\begin{array}{c}\text { Dry Unit } \\
\text { Weight, } \\
\mathrm{kN} / \mathrm{m}^{3}\end{array}$ & $\begin{array}{c}\text { Specific } \\
\text { Gravity }\end{array}$ & $\begin{array}{c}\text { Void ratio, } \\
e\end{array}$ & $\begin{array}{c}\text { Hydraulic } \\
\text { conductivity, } \\
\mathrm{m} / \mathrm{s}\end{array}$ \\
\hline Clean ballast & 15.98 & 2.75 & 0.88 & 0.3 \\
\hline Coal fines & 8.5 & 1.5 & 0.73 & $9 \times 10^{-5}$ \\
\hline Clayey fine sand & 12.5 & 2.6 & 1.04 & $3.7 \times 10^{-6}$ \\
\hline $\begin{array}{l}\text { Kaolin mixed (moisture content }= \\
65 \%)\end{array}$ & 8.9 & 2.51 & 1.73 & $1.3 \times 10^{-9}$ \\
\hline
\end{tabular}


Table 2: Details of experimental test program

\begin{tabular}{|c|c|c|}
\hline Test Material & Test Number & Void Contaminant Index (VCI), \% \\
\hline \multirow{11}{*}{ Coal-fouled ballast } & $\mathrm{CO} 1$ & 0 \\
\hline & $\mathrm{CO} 2$ & 5 \\
\hline & $\mathrm{CO} 3$ & 9 \\
\hline & $\mathrm{CO} 4$ & 18 \\
\hline & $\mathrm{CO5}$ & 28 \\
\hline & $\mathrm{CO6}$ & 38 \\
\hline & $\mathrm{CO} 7$ & 49 \\
\hline & $\mathrm{CO} 8$ & 57 \\
\hline & $\mathrm{CO} 9$ & 77 \\
\hline & $\mathrm{CO} 10$ & 94 \\
\hline & $\mathrm{CO} 11$ & 100 \\
\hline \multirow{11}{*}{ Sand-fouled ballast } & S1 & 0 \\
\hline & $\mathrm{S} 2$ & 1 \\
\hline & S3 & 2 \\
\hline & $\mathrm{S} 4$ & 5 \\
\hline & S5 & 10 \\
\hline & S6 & 20 \\
\hline & S7 & 36 \\
\hline & S8 & 57 \\
\hline & S9 & 75 \\
\hline & S10 & 90 \\
\hline & S11 & 100 \\
\hline \multirow{7}{*}{ Clay-fouled ballast } & CL1 & 0 \\
\hline & CL2 & 2.5 \\
\hline & CL3 & 25 \\
\hline & CL4 & 50 \\
\hline & CL5 & 75 \\
\hline & CL6 & 90 \\
\hline & CL7 & 100 \\
\hline
\end{tabular}


Table 3: Drainage capacity criteria

\begin{tabular}{|c|c|}
\hline Drainage classification & Range \\
\hline Free Drainage & $\mathrm{Q} / \mathrm{Q}_{\mathrm{c}}>100$ \\
\hline Good drainage & $10<\mathrm{Q} / \mathrm{Q}_{\mathrm{c}}<100$ \\
\hline Acceptable drainage & $1<\mathrm{Q} / \mathrm{Q}_{\mathrm{c}}<10$ \\
\hline Poor Drainage & $0.1<\mathrm{Q} / \mathrm{Q}_{\mathrm{c}}<1$ \\
\hline very Poor & $0.001<\mathrm{Q} / \mathrm{Q}_{\mathrm{c}}<0.1$ \\
\hline Impervious & $\mathrm{Q} / \mathrm{Q}_{\mathrm{c}}<0.001$ \\
\hline
\end{tabular}


Table 4: Track drainage classification based on Model 1

\begin{tabular}{|l|c|c|c|r|l|}
\hline \multirow{2}{*}{ case } & \multicolumn{3}{|c|}{ VCI (\%) } & \multirow{2}{*}{} & \\
\cline { 2 - 4 } & Layer 1 & Layer 2 & Layer 3 & \multicolumn{1}{c|}{ Q/Q $_{c}$} & \multicolumn{1}{c|}{$\begin{array}{c}\text { Drainage } \\
\text { classification }\end{array}$} \\
\hline $1-1$ & 0 & 0 & 0 & 110 & Free Drainage \\
\hline $1-2$ & 25 & 0 & 0 & 6.3 & Acceptable Drainage \\
\hline $1-3$ & 25 & 25 & 25 & 7.5 & Acceptable Drainage \\
\hline $1-4$ & 50 & 0 & 0 & 59 & Good Drainage \\
\hline $1-5$ & 50 & 25 & 0 & 23 & Good Drainage \\
\hline $1-6$ & 50 & 25 & 25 & 4 & Acceptable Drainage \\
\hline $1-7$ & 50 & 50 & 0 & 20 & Good Drainage \\
\hline $1-8$ & 50 & 50 & 25 & 1.4 & Acceptable Drainage \\
\hline $1-9$ & 50 & 50 & 50 & 0.045 & Very Poor Drainage \\
\hline $1-10$ & 100 & 0 & 0 & 60 & Good Drainage \\
\hline $1-11$ & 100 & 100 & 0 & 20 & Good Drainage \\
\hline $1-12$ & 100 & 100 & 100 & $8.67 x 10^{-}$ & Impervious \\
\hline $1-13$ & 100 & 50 & 0 & 20 & Good Drainage \\
\hline $1-14$ & 100 & 100 & 50 & 0.0082 & Very Poor Drainage \\
\hline $1-15$ & 100 & 50 & 50 & 0.0238 & Very Poor Drainage \\
\hline $1-16$ & 100 & 100 & 25 & 1.4 & Acceptable Drainage \\
\hline $1-17$ & 100 & 25 & 25 & 4 & Acceptable Drainage \\
\hline $1-18$ & 100 & 50 & 25 & 1.4 & Acceptable Drainage \\
\hline $1-19$ & 0 & 0 & 25 & 60 & Good Drainage \\
\hline $1-20$ & 0 & 0 & 50 & 1.2 & Acceptable Drainage \\
\hline $1-21$ & 25 & 50 & 50 & 1.35 & Acceptable Drainage \\
\hline $1-22$ & 0 & 0 & 100 & 0.00054 & Impervious \\
\hline $1-23$ & 0 & 0 & 75 & 0.1864 & Poor Drainage \\
\hline
\end{tabular}


Table 5: Track drainage classification based on Model 2

\begin{tabular}{|r|r|r|l|}
\hline Case & $\begin{array}{c}\text { Clean ballast } \\
\text { layer thickness } \\
h(\mathrm{~m})\end{array}$ & $\mathrm{Q}$ & \multicolumn{1}{|c|}{$\begin{array}{c}\text { Drainage } \\
\text { classification }\end{array}$} \\
\hline $2-1$ & 0.01 & 0.426 & Poor Drainage \\
\hline $2-2$ & 0.02 & 1.6 & Acceptable Drainage \\
\hline $2-3$ & 0.025 & 3.1 & Acceptable Drainage \\
\hline $2-4$ & 0.03 & 3.7 & Acceptable Drainage \\
\hline $2-5$ & 0.05 & 7.4 & Acceptable Drainage \\
\hline $2-6$ & 0.1 & 20 & Good Drainage \\
\hline $2-7$ & 0.2 & 60 & Good Drainage \\
\hline $2-8$ & 0.3 & 110 & Free Drainage \\
\hline
\end{tabular}


Table 6: Track drainage classification based on Model 3

\begin{tabular}{|c|c|c|c|c|c|c|}
\hline \multirow[b]{2}{*}{ case } & \multicolumn{4}{|c|}{ VCI (\%) } & \multirow[b]{2}{*}{$\mathrm{Q} / \mathrm{Q}_{\mathrm{c}}$} & \multirow[b]{2}{*}{ Drainage criteria } \\
\hline & Layer 1 & Layer 2 & Layer 3 & Layer 4 & & \\
\hline $3-1$ & 0 & 0 & 0 & 0 & 110 & Free Drainage \\
\hline $3-2$ & 0 & 0 & 50 & 0 & 1.7 & Acceptable \\
\hline $3-3$ & 50 & 0 & 0 & 0 & 92 & Good Drainage \\
\hline $3-4$ & 50 & 50 & 0 & 0 & 69 & Good Drainage \\
\hline $3-5$ & 50 & 50 & 50 & 0 & 0.165 & Poor Drainage \\
\hline $3-6$ & 50 & 50 & 25 & 0 & 15 & Good Drainage \\
\hline $3-7$ & 100 & 0 & 0 & 0 & 92 & Good Drainage \\
\hline $3-8$ & 100 & 100 & 0 & 0 & 69 & Good Drainage \\
\hline $3-9$ & 100 & 100 & 25 & 0 & 15 & Good Drainage \\
\hline $3-10$ & 100 & 100 & 100 & 0 & 0.0000318 & Impervious \\
\hline $3-11$ & 100 & 50 & 0 & 0 & 69 & Good Drainage \\
\hline $3-12$ & 100 & 50 & 25 & 0 & 15 & Good Drainage \\
\hline $3-13$ & 100 & 100 & 50 & 0 & 0.113 & Poor Drainage \\
\hline $3-14$ & 0 & 0 & 0 & 25 & 14 & Good Drainage \\
\hline $3-15$ & 25 & 25 & 25 & 25 & 7.5 & Acceptable \\
\hline $3-16$ & 50 & 0 & 0 & 25 & 10.6 & Good Drainage \\
\hline $3-17$ & 50 & 50 & 0 & 25 & 7.2 & Acceptable \\
\hline $3-18$ & 50 & 50 & 25 & 25 & 4.6 & Acceptable \\
\hline $3-19$ & 50 & 50 & 50 & 25 & 0.161 & Poor Drainage \\
\hline $3-20$ & 100 & 0 & 0 & 25 & 11 & Good Drainage \\
\hline $3-21$ & 100 & 100 & 0 & 25 & 7.1 & Acceptable \\
\hline $3-22$ & 100 & 100 & 25 & 25 & 4.6 & Acceptable \\
\hline $3-23$ & 100 & 100 & 100 & 25 & 0.0000318 & Impervious \\
\hline $3-24$ & 100 & 50 & 0 & 25 & 7.1 & Acceptable \\
\hline $3-25$ & 100 & 50 & 25 & 25 & 4.6 & Acceptable \\
\hline $3-26$ & 100 & 100 & 50 & 25 & 0.111 & Poor Drainage \\
\hline $3-27$ & 0 & 0 & 0 & 50 & 0.11 & Poor Drainage \\
\hline $3-28$ & 25 & 0 & 0 & 50 & 0.091 & Very Poor \\
\hline $3-29$ & 25 & 25 & 25 & 50 & 0.076 & Very Poor \\
\hline $3-30$ & 50 & 0 & 0 & 50 & 0.077 & Very Poor \\
\hline $3-31$ & 50 & 25 & 0 & 50 & 0.077 & Very Poor \\
\hline $3-32$ & 50 & 25 & 25 & 50 & 0.079 & Very Poor \\
\hline $3-33$ & 50 & 50 & 0 & 50 & 0.0616 & Very Poor \\
\hline $3-34$ & 50 & 50 & 25 & 50 & 0.0613 & Very Poor \\
\hline $3-35$ & 50 & 50 & 50 & 50 & 0.045 & Very Poor \\
\hline $3-36$ & 100 & 0 & 0 & 50 & 0.069 & Very Poor \\
\hline $3-37$ & 100 & 100 & 0 & 50 & 0.0456 & Very Poor \\
\hline $3-38$ & 100 & 100 & 100 & 50 & 0.0000313 & Impervious \\
\hline $3-39$ & 100 & 50 & 0 & 50 & 0.0534 & Very Poor \\
\hline $3-40$ & 100 & 100 & 50 & 50 & 0.0275 & Very Poor \\
\hline $3-41$ & 0 & 0 & 0 & 100 & 0.0000175 & Impervious \\
\hline $3-42$ & 50 & 0 & 0 & 100 & 0.0000148 & Impervious \\
\hline $3-43$ & 50 & 50 & 0 & 100 & 0.0000175 & Impervious \\
\hline $3-44$ & 50 & 50 & 50 & 100 & 0.0000175 & Impervious \\
\hline $3-45$ & 100 & 0 & 0 & 100 & 0.0000148 & Impervious \\
\hline $3-46$ & 100 & 100 & 0 & 100 & 0.0000175 & Impervious \\
\hline $3-47$ & 100 & 100 & 100 & 100 & $8.67 \times 10^{-06}$ & Impervious \\
\hline $3-48$ & 100 & 50 & 0 & 100 & 0.0000148 & Impervious \\
\hline $3-49$ & 100 & 100 & 50 & 100 & 0.0000118 & Impervious \\
\hline
\end{tabular}



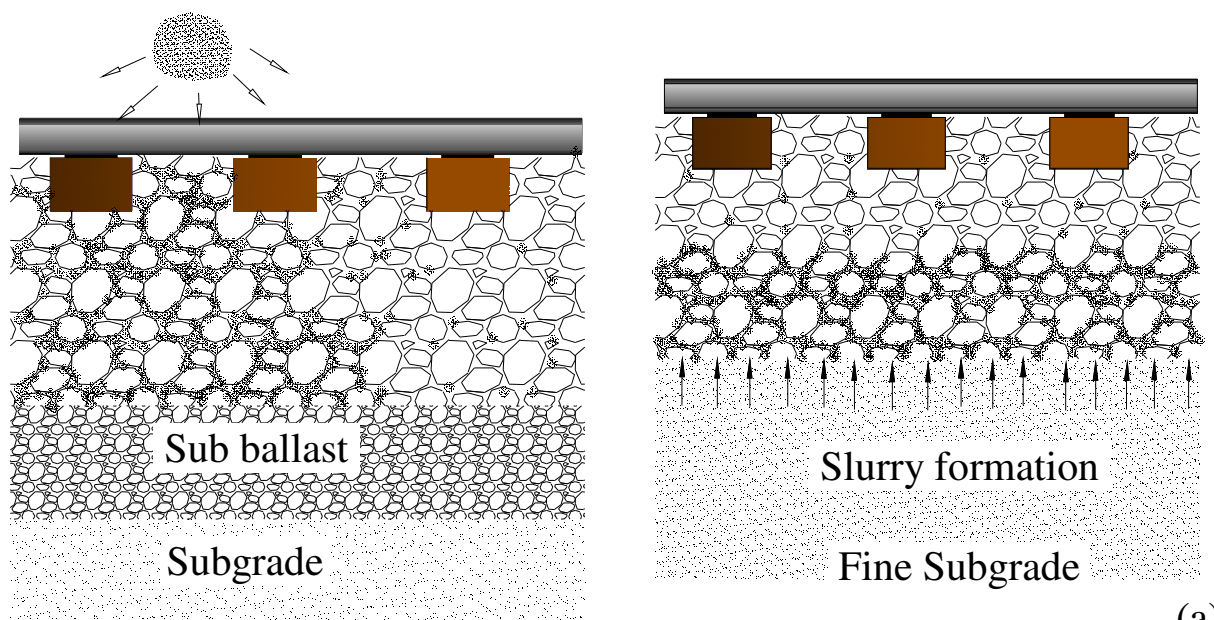

(b)

Figure 1: ballast fouling (a) surface infiltration (b) subgrade infiltration 


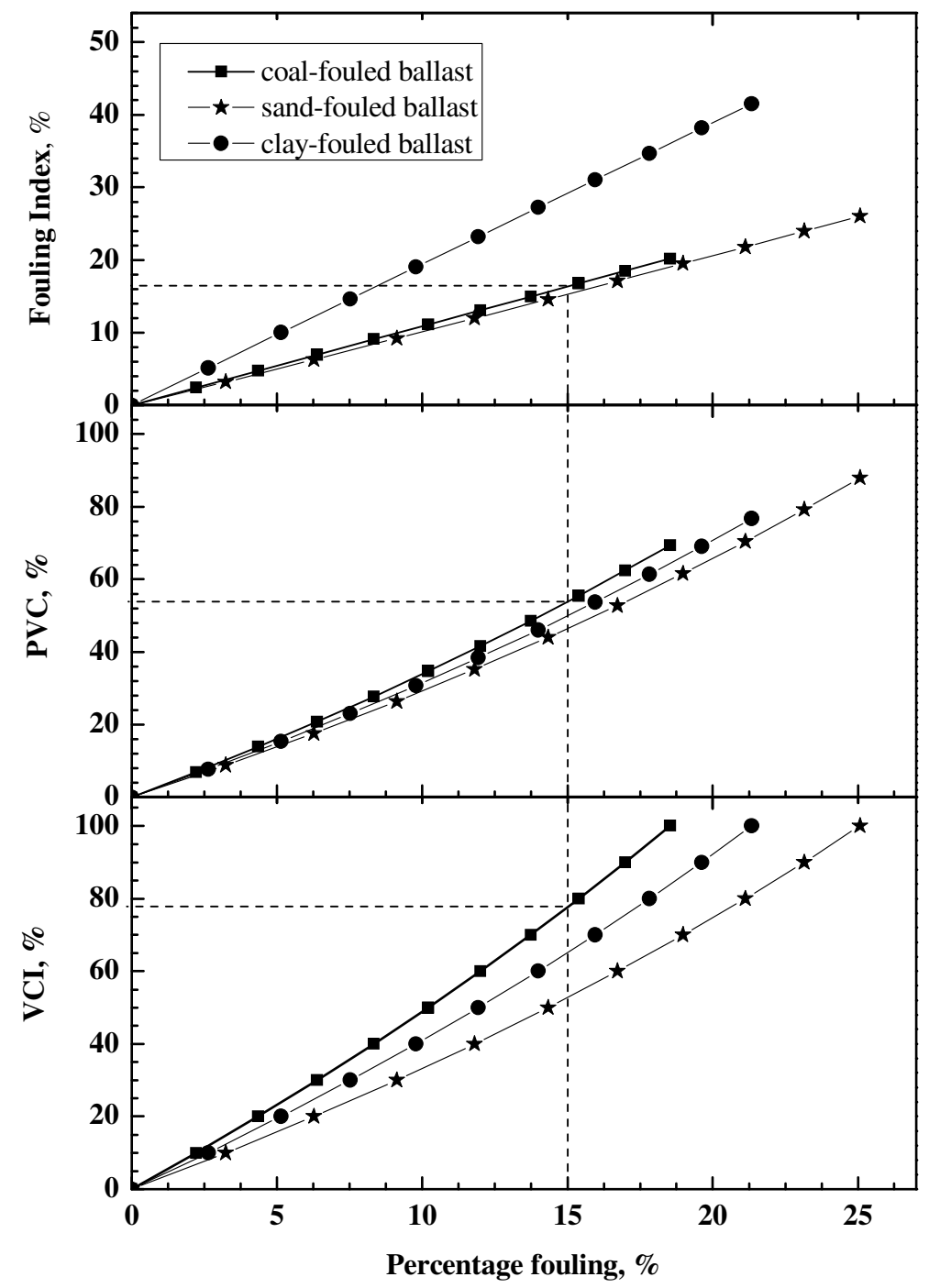

Figure 2: Comparison between Fouling Index, Percentage Void Contamination and Void Contaminant Index for various ranges of Percentage of Fouling 


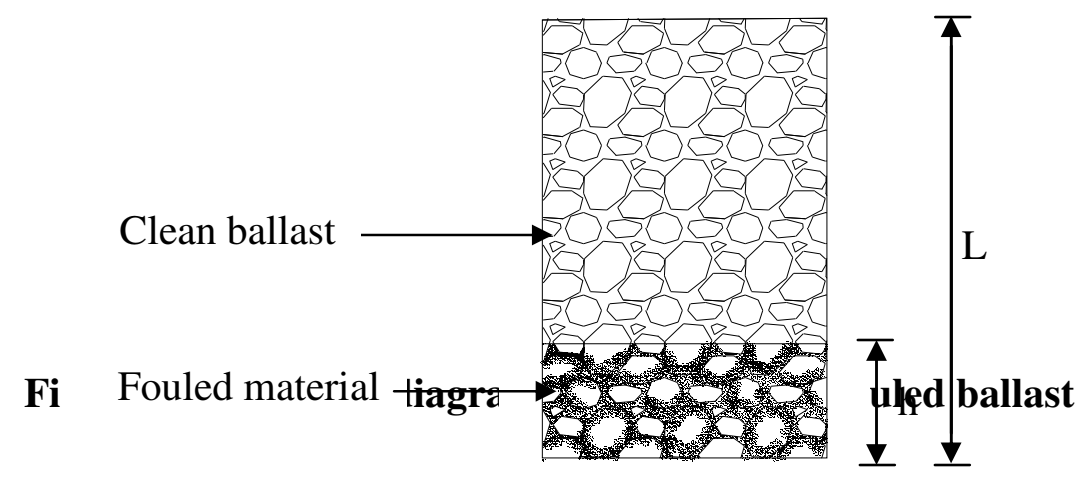




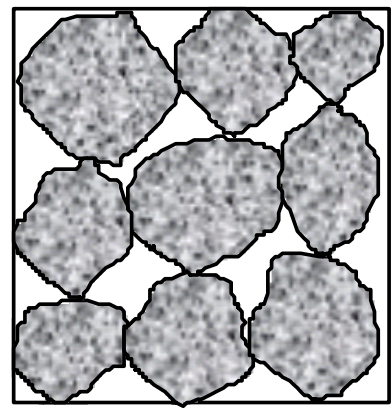

(a)

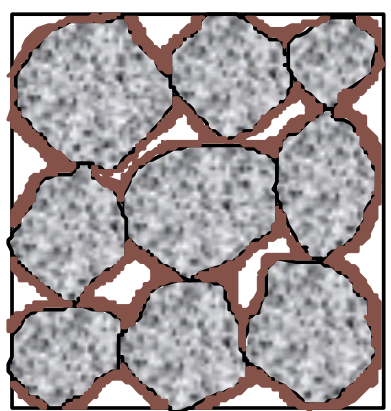

(b)

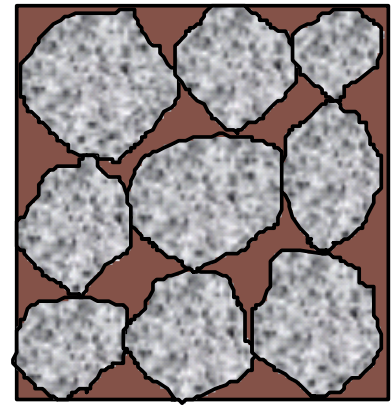

(c)

Figure 4: Fouling status (a) fresh ballast, (b) partially fouled ballast and (c) fully fouled ballast 


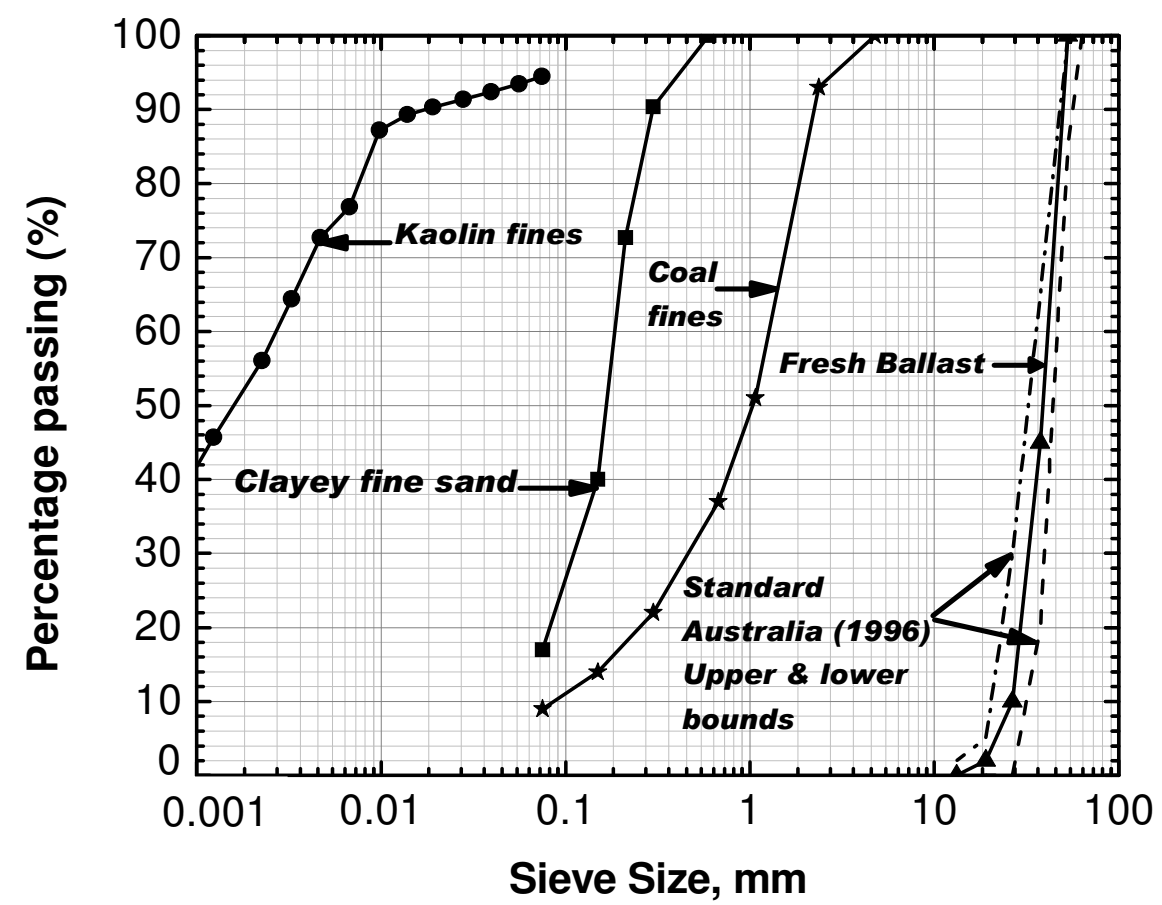

Figure 5: Gradations of clean ballast and fouling materials 


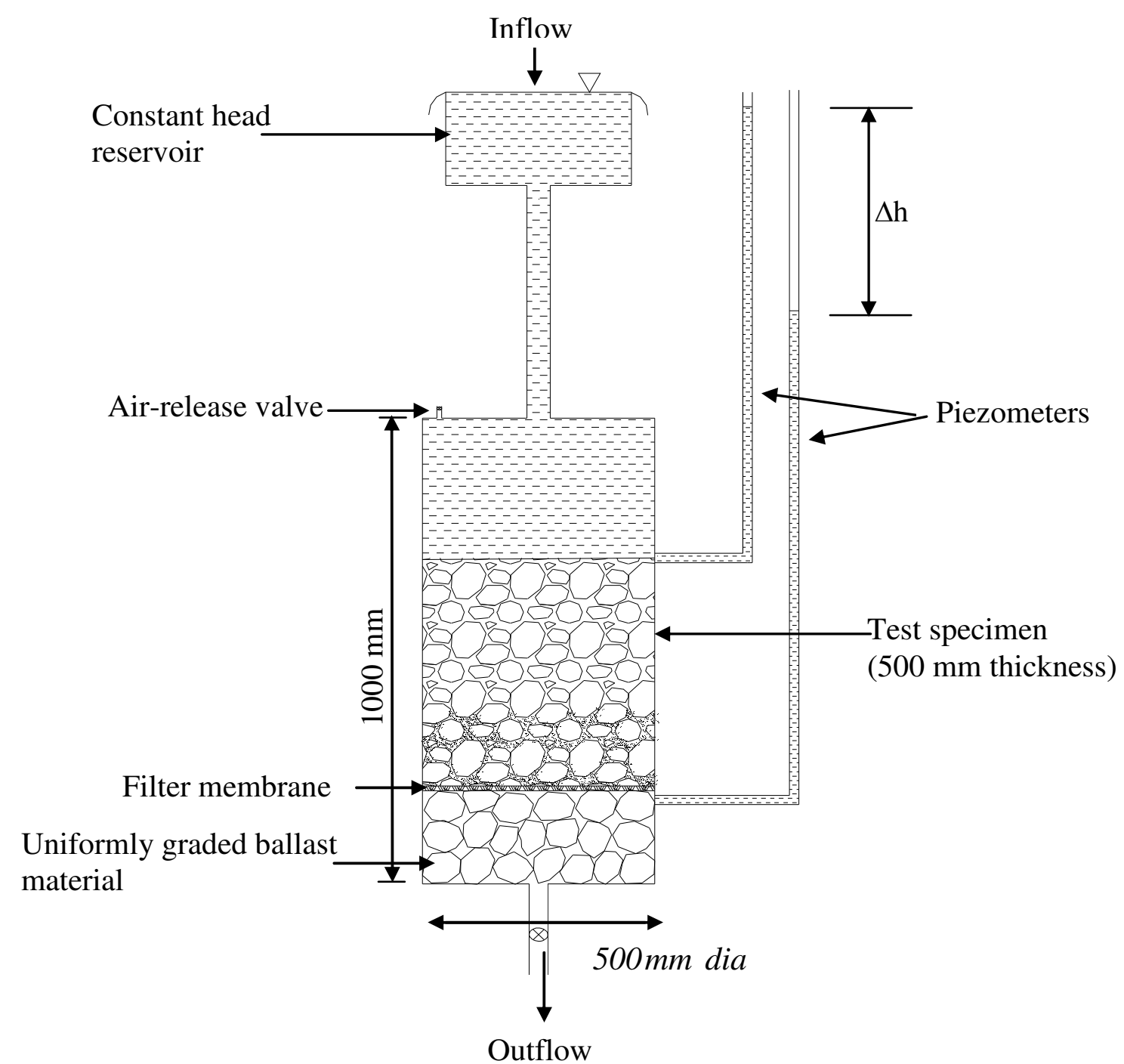

Figure 6: Schematic diagram of large-scale permeability test apparatus 


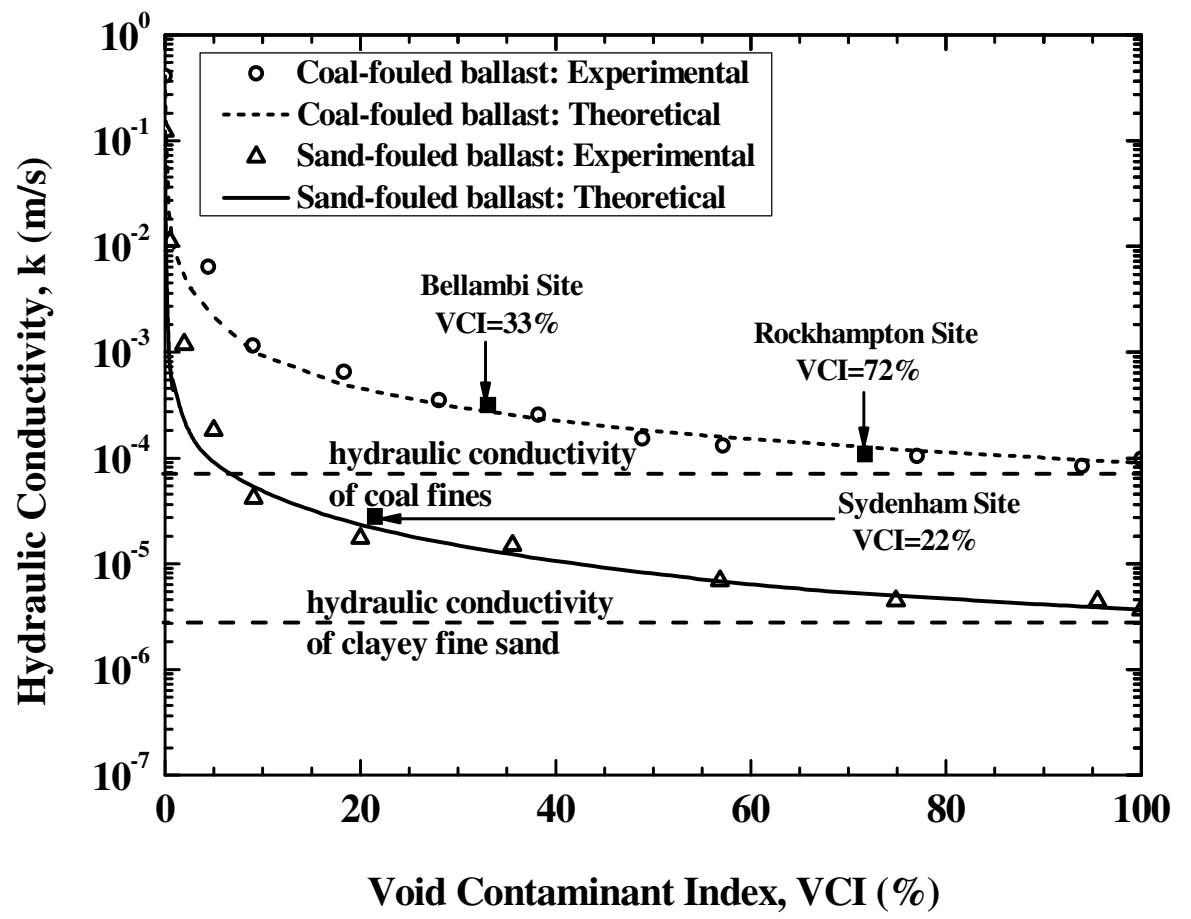

(a)

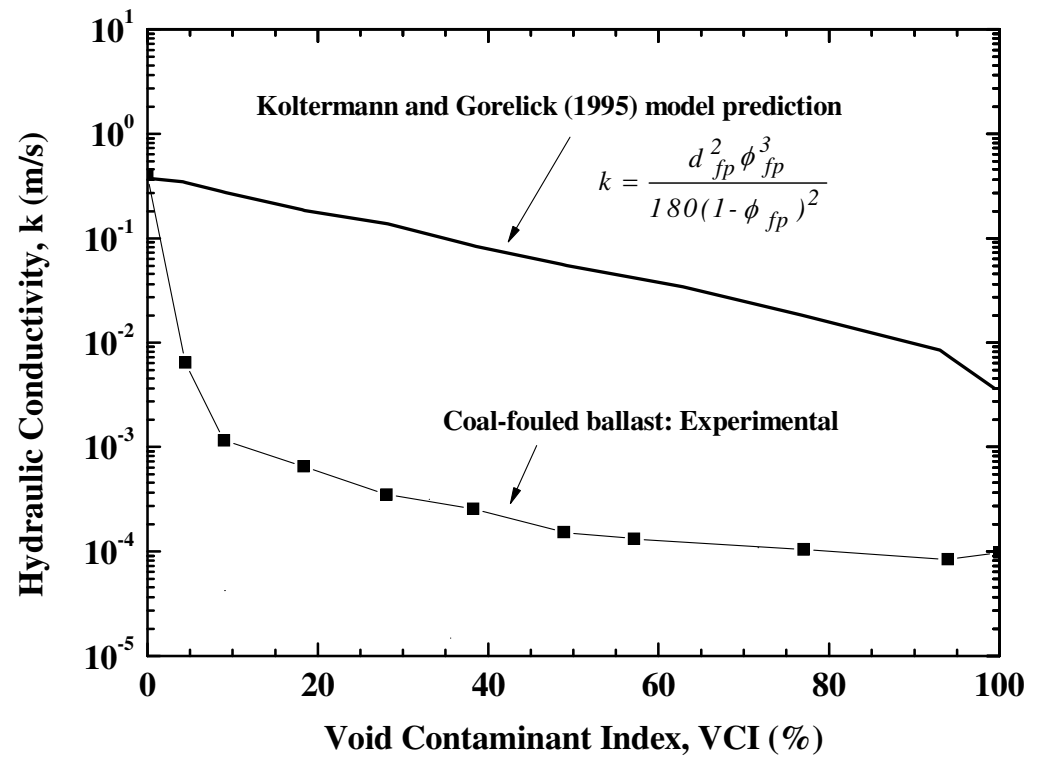

(b)

Figure 7: Variation of hydraulic conductivity vs. Void Contaminant Index for (a) coalfouled ballast and sand-fouled ballast and (b) coal fouled-ballast with existing model 


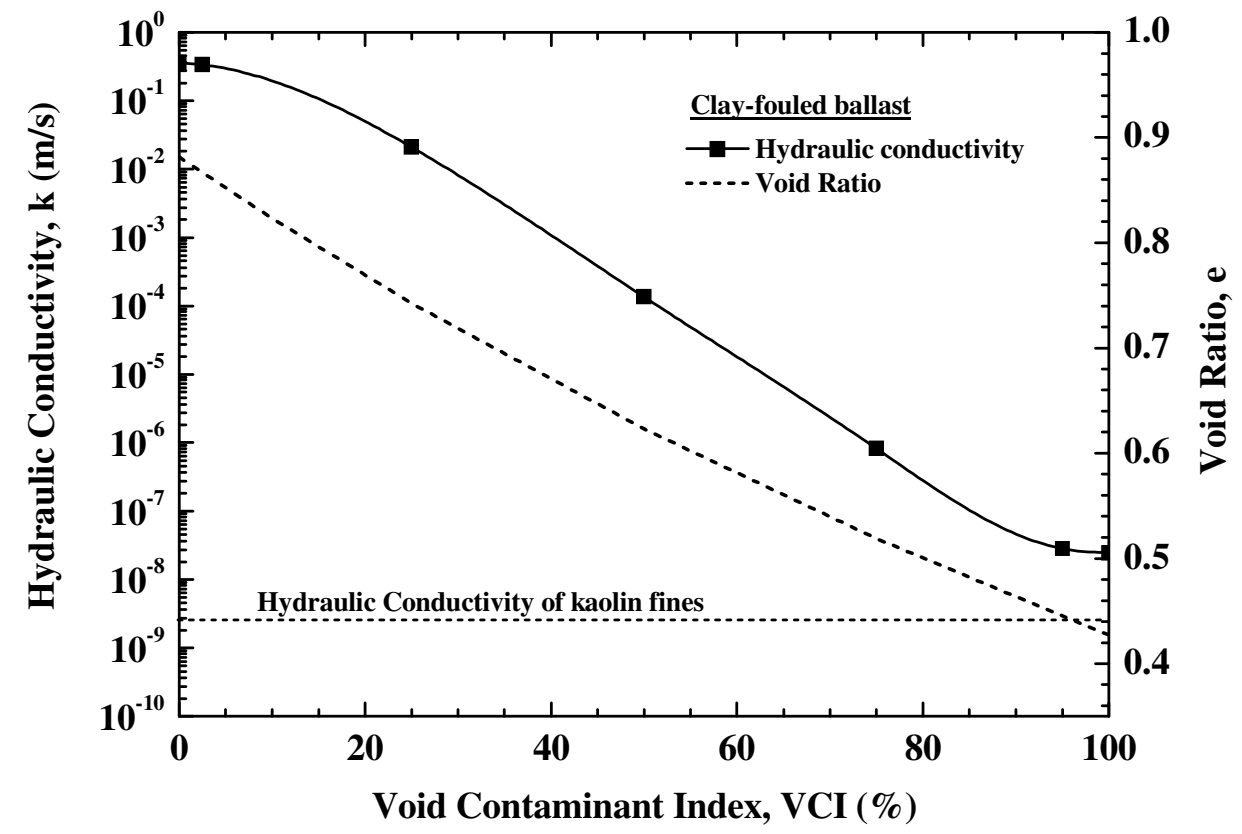

Figure 8: Variation hydraulic conductivity with Void Contaminant Index for uniform clay-fouled ballast 


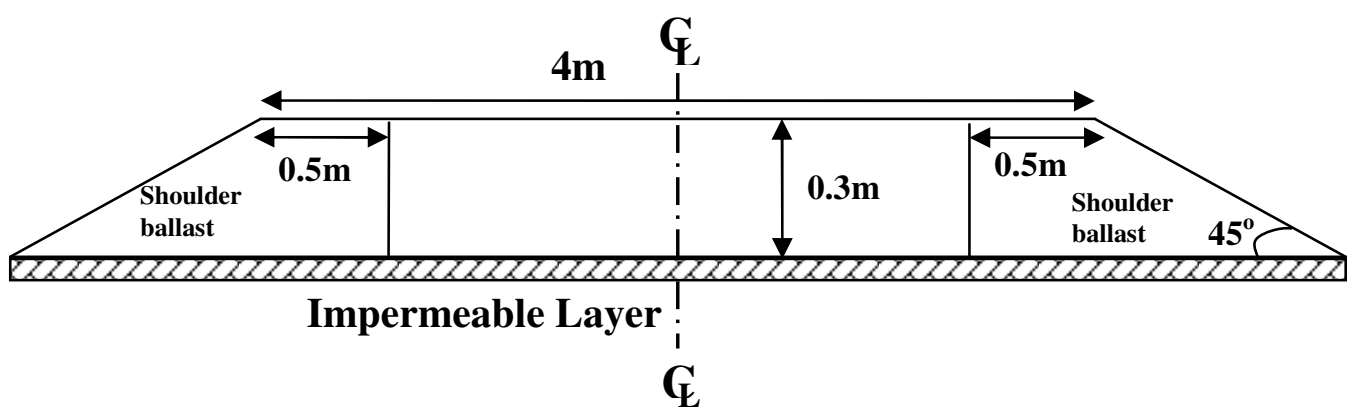

(a)

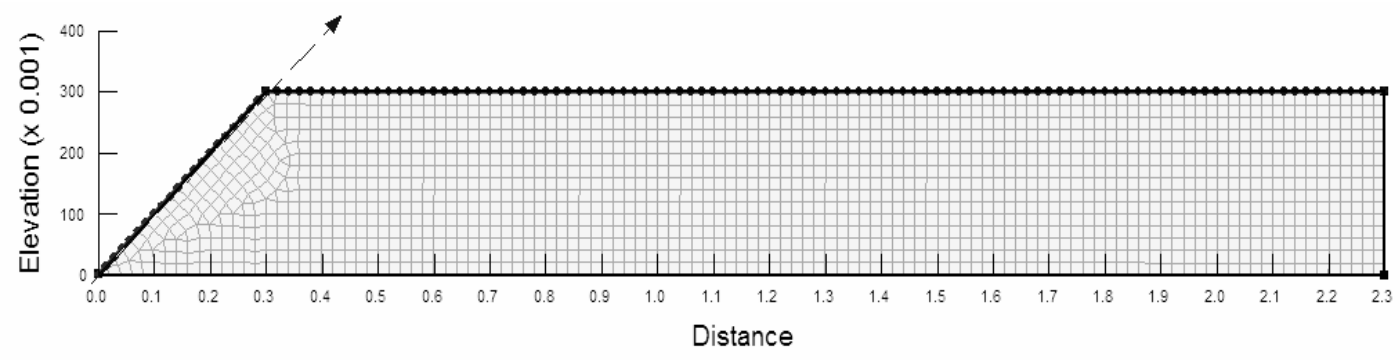

(b)

Figure 9: (a) Vertical cross section of the typical ballast layer used in seepage analysis and (b) Discretization of one-half track 


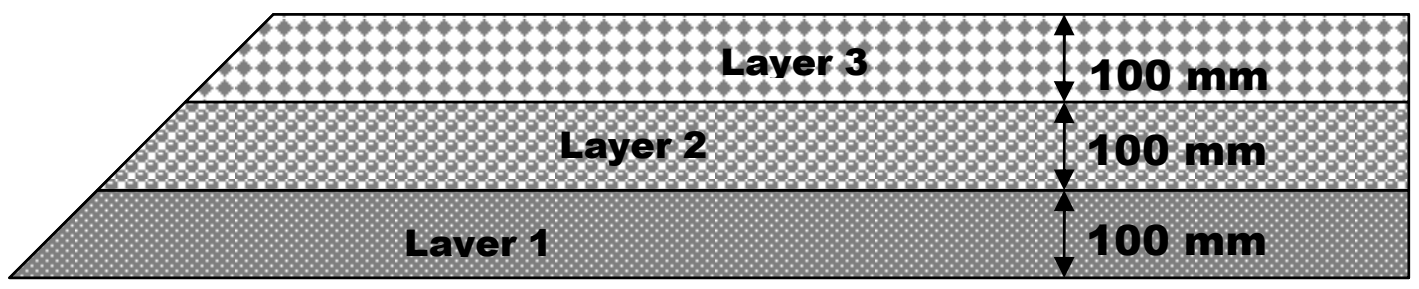

(a)

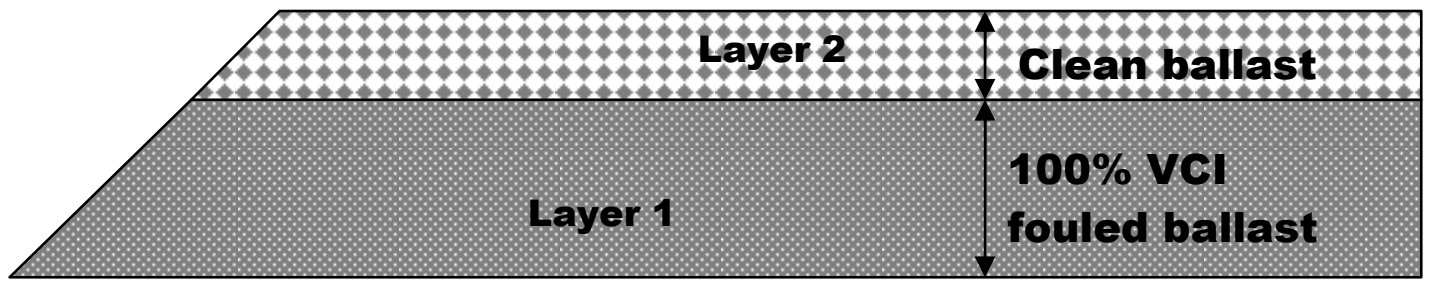

(b)

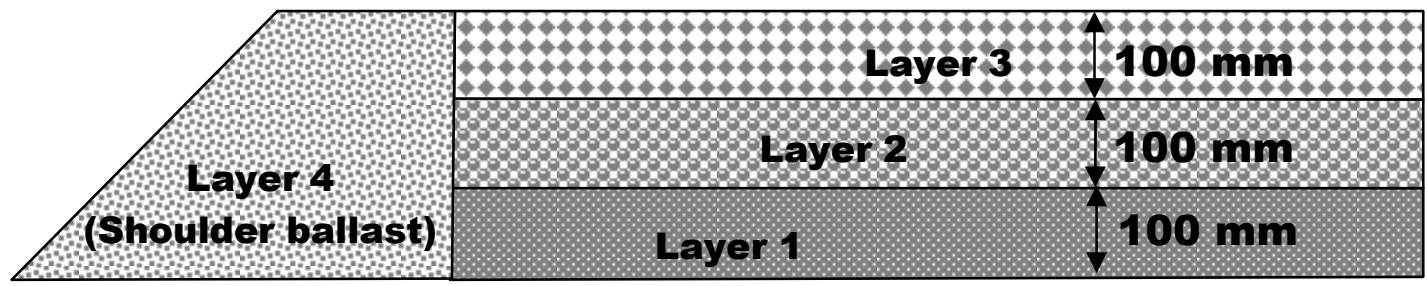

(c)

Figure 10: Fouled ballast patterns (a) Model 1, (b) Model 2 and (c) Model 3 


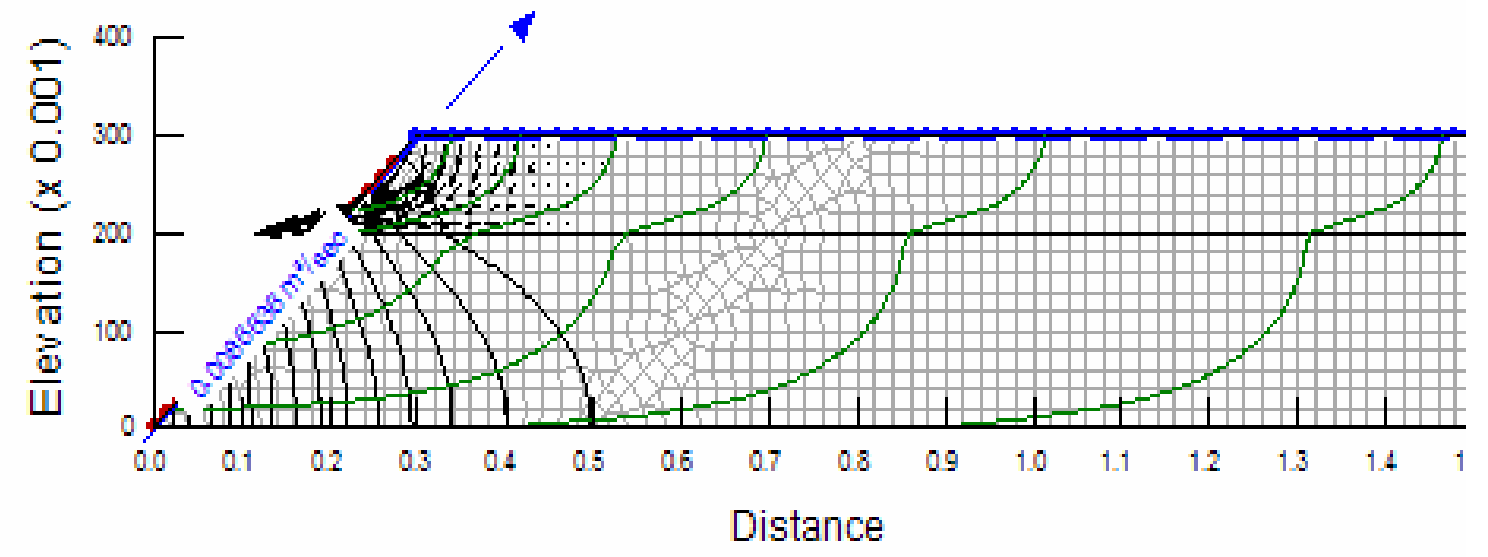

Figure 11: Typical output of numerical Seepage analysis (Model 2) 


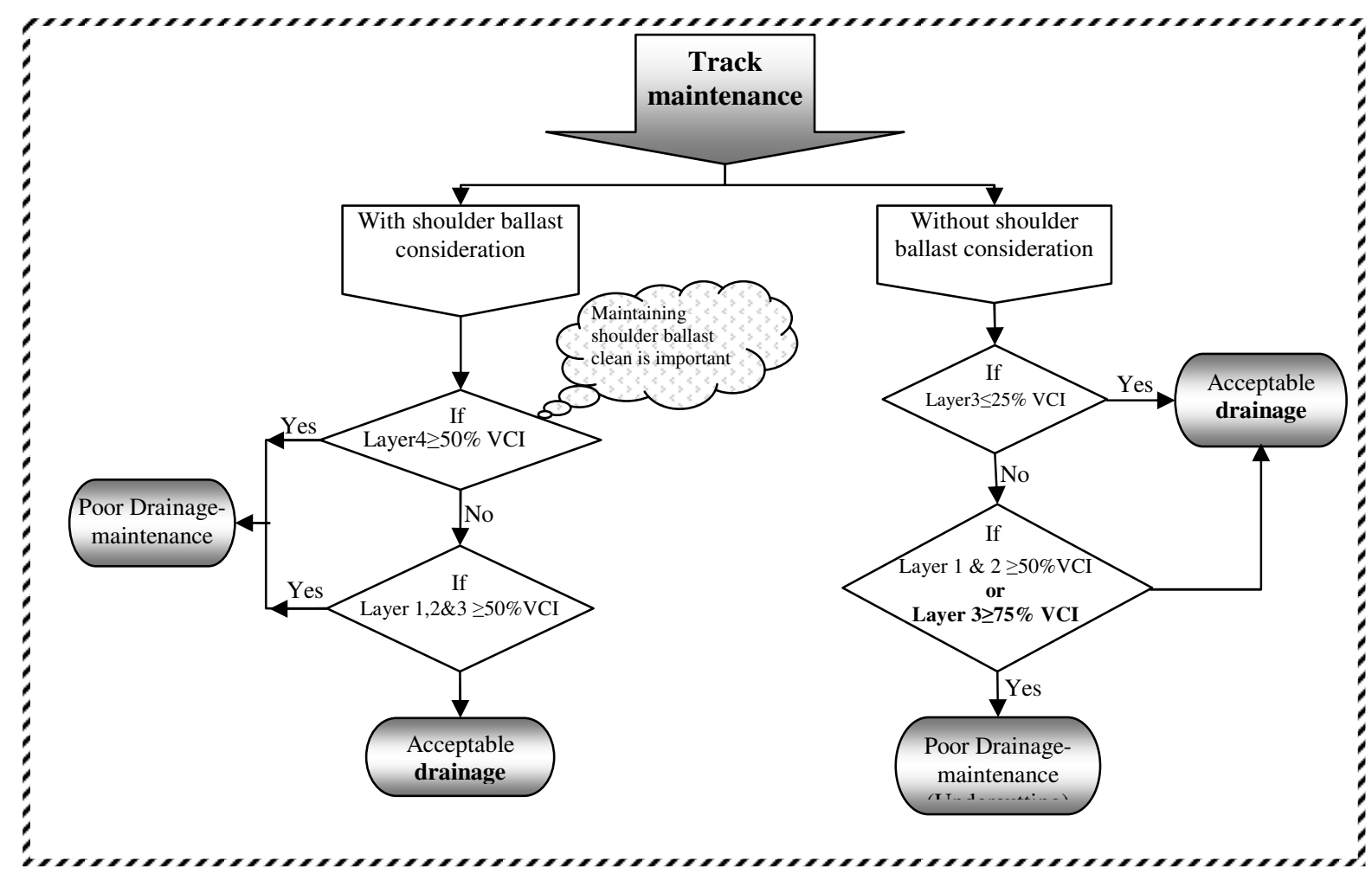

Figure 12: Maintenance Chart 


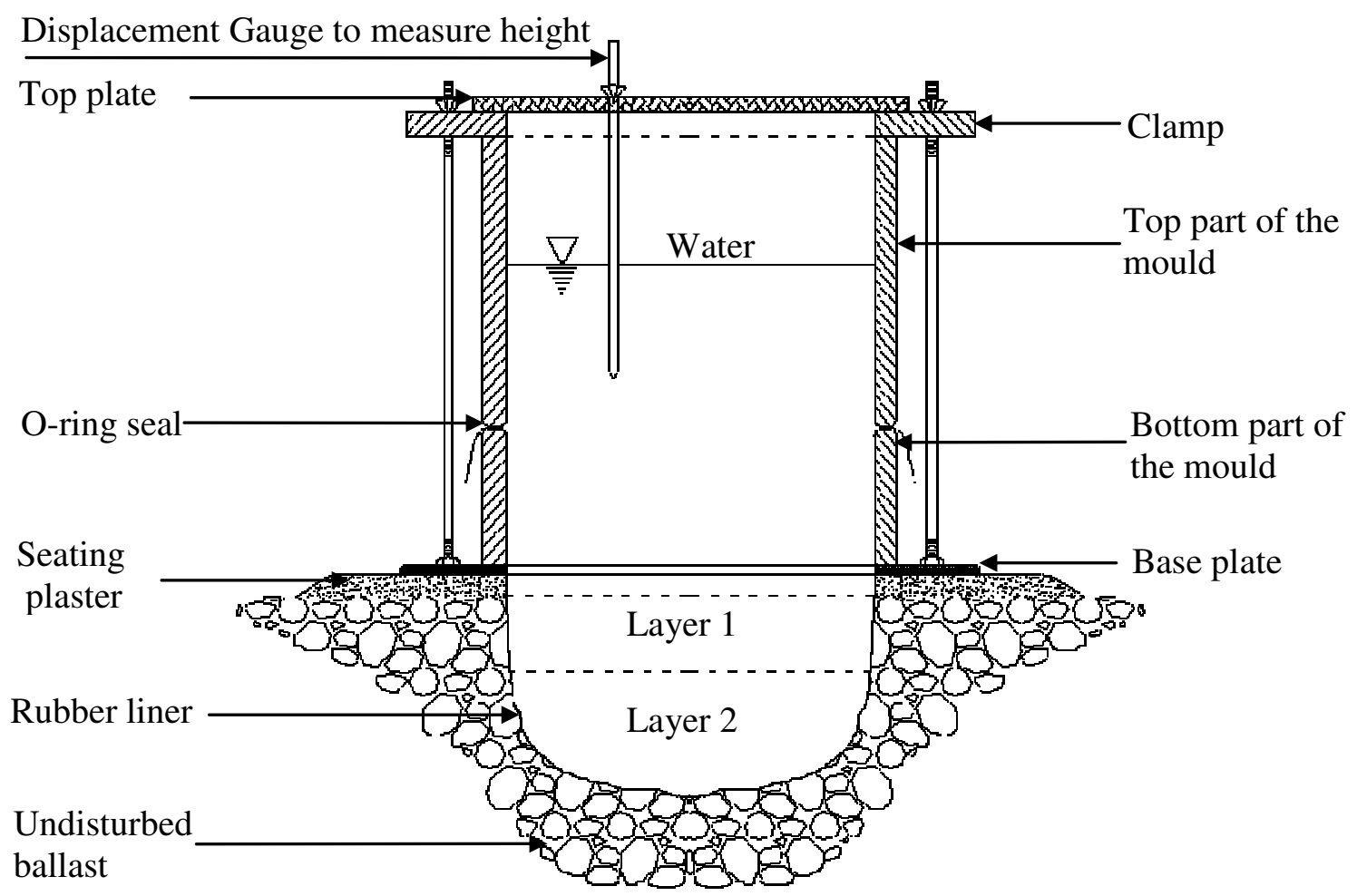

Figure A1: Field test set up for determining VCI 